This is an electronic reprint of the original article. This reprint may differ from the original in pagination and typographic detail.

Author(s): Rautamies, Erja; Vähäsantanen, Katja; Poikonen, Pirjo-Liisa; Laakso, Marja-Leena

Title: $\quad$ Parental agency and related emotions in the educational partnership

Year: $\quad 2019$

Version:

Please cite the original version:

Rautamies, E., Vähäsantanen, K., Poikonen, P.-L., \& Laakso, M.-L. (2019). Parental agency and related emotions in the educational partnership. Early Child Development and Care, 189(6), 896-908.

https://doi.org/10.1080/03004430.2017.1349763

All material supplied via JYX is protected by copyright and other intellectual property rights, and duplication or sale of all or part of any of the repository collections is not permitted, except that material may be duplicated by you for your research use or educational purposes in electronic or print form. You must obtain permission for any other use. Electronic or print copies may not be offered, whether for sale or otherwise to anyone who is not an authorised user. 
Accepted 16.06.2017 Early Child Development and Care

\title{
Parental agency and related emotions in the educational partnership
}

Erja Rautamies, Katja Vähäsantanen, Pirjo-Liisa Poikonen \& Marja-Leena Laakso

Faculty of Education and Psychology, University of Jyväskylä, Finland

\begin{abstract}
This study investigated the understudied issue of parental agency and related emotions in the educational partnership in the context of Finnish early childhood education and care. We asked i) what types of parental agency can be identified in the educational partnership and ii) in what ways are emotions related to these types of agency. The narrative method was used to analyse the interview data of parents of children with difficulties in self-regulation. The findings indicate that parental agency in the educational partnership varied from proactive and confrontational to hindered. Typically, pleasant emotions were related to proactive and unpleasant emotions to confrontational parental agency. Ambivalent and neutral emotions in turn were related to hindered parental agency. This study enhances understanding of the educational partnership from the viewpoint of parents of a child with difficulties in selfregulation. The study also contributes to the theoretical debate on the emotions related to agency.
\end{abstract}


Keywords: early childhood education, educational partnership, emotions, narrative research, parental agency, self-regulation

\section{Introduction}

This study addresses parental agency in the educational partnership in the early childhood education setting. The importance of the educational partnership has been strongly emphasized in several studies that have concluded that close collaboration between parents and educators ensure the best conditions for children's development and learning (BlueBanning, Summers, Frankland, Nelson \& Beegle, 2004; Hoover-Dempsey, Whitaker \& Ice, 2010; Reynolds \& Schlafer, 2010). Summers and colleagues (2005, p. 66) define an educational partnership as "mutually supportive interaction between families and professionals focused on meeting the needs of children and families". In practice, this means, for example, sharing information about a child (Rimm-Kaufman \& Pianta, 2005) in order to gain an overall picture of the child, including the challenges facing the child and the child's strengths and individual needs. A successful educational partnership also has a positive impact on parental support (Foot, Howe, Cheyne, Terras \& Rattray, 2002).

Parental agency can be interpreted to be an important goal of, and a prerequisite for, a successful educational partnership (e.g. Murray, McFarland-Piazza \& Harrison, 2015; Sandberg \& Vuorinen, 2008; Zellman \& Perlam, 2006). However we need more understanding of the manifestation of parental agency in the educational partnership in early childhood education contexts. In this study, we see parental agency mostly in terms of the behavioral and communicational actions by parents on behalf of their child in the relationship with educators. For parents, this means influencing and taking a stance via discussions and negotiations of meaningful goals and practices for supporting their child. Generally, parental agency aims at influencing early childhood education and promoting the wellbeing of a child in a daycare center.

This study was carried out in the context of early childhood education and care (ECEC) in Finland. The National Curriculum Guidelines on ECEC in Finland (2016) and the National Core Curriculum for Pre-primary Education 2014 (2016) emphasize the importance of collaboration with parents when supporting children's welfare, learning and development. Parental agency is especially important in drawing up the individual educational plan (IEP) (see Karila \& Alasuutari, 2012) required for every child in the Finnish ECEC system according to the revised Early Childhood Education Act (1973/2015). The availability of 
early support emphasized in the above-mentioned curricula rest on the agency and successful collaboration of both parties in the educational partnership.

Successful collaboration and the appropriate exercise of parental agency are especially important for supporting children who have been identified as exhibiting problem behavior and difficulties in their social and emotional development typical for children with difficulties in self-regulation (Webster-Stratton \& Reid, 2010). Such problems may manifest as difficulties in regulating impulses and strong emotions (aggression, frustration and fear), and difficulties in playing and interacting with other children (sharing, cooperating, playing and making friends) and following general rules (Webster-Stratton \& Reid, 2010). These difficulties may challenge the learning, development and wellbeing of the child, and they may also complicate the peer relations and parent-teacher relationship (Rautamies, Poikonen, Vähäsantanen \& Laakso, 2016). Thus far, we do not have much information about parental agency in the ECEC context. In particular, we need more understanding of the role of parental agency in the case of children having these kinds of difficulties

Agency has often been understood as humans' rational, intentional and goal-oriented activity (Giddens, 1984). However, emotional aspects also play an important role in subjects' agency (see Barnes, 2000; Hökkä, Vähäsantanen, Paloniemi \& Eteläpelto, 2017). Emotions (e.g. Chen, 2016; Schutz, Hong, Cross \& Osbon, 2006) and agency (e.g. Lipponen \& Kumpulainen, 2011) have mainly been studied in the field of education, but the connections between them are not well understood (Barnes, 2000; Hökkä et al., 2017). Challenged by this gap in the literature, we were especially interested in further understanding of parental agency and related emotions in the educational partnership specifically in the early childhood education setting. This study is based on interviews with 23 Finnish parents of children with difficulties in self-regulation, i.e. difficulties in regulating their behavior and emotions. The narrative approach was applied when analyzing the interview data (see Riessman, 2008). This study aimed at enriching understanding of the educational partnership from the parental point of view and to offer tools that can assist educators in achieving a successful educational partnership. The study also contributes to the theoretical debate on the meaning of emotions in relation to agency.

\section{Agency: theoretical considerations}

\section{Contextual and relational dimensions of agency}


Agency refers to the presence, participation and active influence of individuals in their social, cultural and material environment, in other words, engagement in activities and the use of power for the purpose of exerting influence in social situations (Eteläpelto, Vähäsantanen, Hökkä \& Paloniemi, 2013; Giddens, 1984). Agency is enacted in the form of discursive, practical and embodied actions and relations with the world (Archer, 2000). Agency is often understood as proactive and change-oriented action manifested via taking stances and making suggestions, but it can also be manifested through resistance to expected or ongoing actions (Eteläpelto et al., 2013).

We approached agency by utilizing its personal and structural (contextual) dimensions (Eteläpelto et al., 2013). Specifically, this study focuses on the contextual and relational dimensions of agency. We assume that parental agency in the educational partnership is enacted relationally (Edwards, 2005) together with the educators. The educational partnership sets a common goal relating to the target child's wellbeing, development and learning. We presume that parents' experiences of the educational partnership have an influence on their agency. Drawing on the notions presented by Emirbayer \& Mische (1998), we also presume that situational, contextual, structural and socio-cultural factors, such as ECEC practices and power-relations, are the frames within which parental agency is exercised. Although our present focus was on the contextual and relational dimensions of agency, we agree with the view that personal factors also have an influence on parental agency.

Griffiths, Norwich and Burden (2004) furthered understanding of the parental partnership in the school context in their study of the agency in parent-professional communication of the mothers of children with dyslexia. Honkasilta, Vehkakoski and Vehmas (2015) also studied parental agency in the school context by analyzing the agency of mothers of children with diagnosed ADHD. The authors identified three categories of agency: mothers' volitional strong agency (active partners), forced strong agency (e.g. advocators, aggressive agents) and weak agency (e.g. bystanders, withdrawing agents). Archer (2003) similarly showed that agency can vary across different situations and over time.

In our study parental agency refers to parents' behavioral and communicational activities in their relationship with ECEC educators. The aim of parental agency is to influence early childhood education and the wellbeing of a child in a daycare center. In practice, this means parental initiatives and actions, information-seeking, initiating discussions, being present and participating in formal and informal interactional situations and collaboration with educators. Parents can choose for example whether to participate or not at parents' meetings, and to communicate or not with educators in pick-up and drop-off 
situations. In the Finnish ECEC context, we assume that parental agency is enacted relationally with educators and influenced by the values, norms, rules, institutional practices and material and physical circumstances of the specific daycare center.

\section{Emotions related to agency}

Emotions are a motivating force for human activity (Turner \& Stets, 2005, p. 19), which is why it is important to study the connection between emotions and agency (Hökkä et al., 2017). Emotions can be defined as emotional reactions (or strong feeling) deriving from one's personal circumstances, including specific events, social situations and social relationships with others (Hökkä et al., 2017; Oxford Living English Dictionary). Emotions are socially constructed and personally enacted and connected to the attainment of personal goals, and the maintenance of standards or beliefs pertaining to social situations (Schutz et al., 2006, p. 344). Emotions are experienced, negotiated and expressed in social contexts via social practices and interaction (Vähäsantanen \& Eteläpelto, 2015).

Studies on emotions in relation to agency have indicated a strong reciprocal connection between emotions and the enactment of professional agency (e.g. Hökkä et al., 2017; Vähäsantanen \& Eteläpelto, 2015). For example, enacting agency fostered positive emotions and vice versa. However the connection between negative emotions and enacting agency seem to be more complicated: negative emotions were related to resisting agency and taking a critical stance, but also to constructive, active agency (Hökkä et al., 2017).

In this study we adopted the circumplex model of emotions which contains two dimensions of emotions (valence and arousal) (Widen \& Russell, 2010). According to the model the nature of emotions variate from unpleasant to pleasant and the arousal intensity of emotions vary from low to high (Posner, Russell, Peterson, 2005). Pleasant emotions include emotions like love, joy, pleasure, satisfaction, pride, excitement and surprise and unpleasant emotions include emotions like fear, anger, frustration, anxiety, sadness, distress, guilt and shame (see Chen, 2016). In this study, we were interested in all the verbal expressions of emotions communicated by the parents during the interview when reflecting on their agency in the educational partnership.

\section{Research aims and questions}


Our aim in this study was to investigate parental agency in the educational partnership and the emotions related to the types of agency found. The following research questions were set:

1. What types of parental agency can be identified in the educational partnership in the ECEC context?

2. How are different kinds of emotions related to these types of agency?

\section{Methods}

\section{Utilizing narrative method in this study}

The narrative approach was used to analyze the interview data (Riessman, 2008). This study emphasizes the meaning of narratives as a meaning-making process for the informants (Elliott, 2005), and arising from the sharing of experiences with others (Bruner, 1990). Narratives contain cognitive and emotional aspects informing the audience about what happened and how the subject experienced the events in question (Bruner, 1990). The narrative method is very useful when investigating emotionally rich experiences (e.g., Hänninen, 2000). Emotions are related to the individual's needs, goals and intentions (Hänninen, 2000). The emotional aspects of narration are often based on moral reflection on one's own and other people's actions which in turn are based on interpretations of the intentions, responsibilities and duties of the actors in social situations (Hänninen, 2000; Singer, 1995). Strong emotional experiences are related to issues which threaten or advance values important to the subject (Singer, 1995).

In this interview study, we investigated parental agency, and related emotions, in the educational partnership. We focused especially on parents' narrated emotions related to their experiences of their agency in the educational partnership. Instead of a real and objective reality this study proposes a subjective and relativist reality (Spector-Mersel, 2010). Interpretations of a person's experiences are also influenced by the cultural-historical context as well as the immediate social and interactional context influence (Burr, 2003). It also should be noted that parents' reflection on, and interpretations and emotional descriptions of, their experiences of agency in the educational partnership may change over time, i.e., across narrative occasions (see Hökkä et al., 2017). In this study, we emphasize the social nature of narratives (Elliott, 2005). The parents' narratives were produced in interaction with the researcher. Thus an interview can be seen as a social and dialogical situation in which the 
informant is a purposeful actor (Riessman, 2008, 8, 23-27). For parents, an interview situation may, for example, offer a possibility to share experiences, gain understanding, or find a moral justification for the behavior of the actors.

\section{Participants and data collection}

The data consisted of 23 interviews (18 mothers and 5 fathers) of the parents who had been clients of ECEC services for at least 10 months and who thought their child behaved challengingly, i.e., had difficulties in controlling their behavior and emotions, were invited to participate in the study. Most of the children were 6-7 -year olds $(n=17)$ when the interviews were conducted, and almost all of them were boys (girls only in 3 interviews). Most of the participating parents had been clients of ECEC services for several years. Most of them $(n=$ 15) were reached via the so called "Family School" program (for more details, see Rautamies et al., 2016). The remaining parents $(n=8)$ were recruited by sending a research-request to daycare centers, primary schools (first-grade classrooms) and the local ADHD association. Participation in the study was voluntary. Before signing the research consent, all parents were informed about the aim of the study and its ethical principles (confidentiality and sensitivity), such as anonymity, i.e., that no parent, child, educator or daycare center would be identifiable in any of the study reports. The first two interviews were conducted 2009. After elaborating slightly the research procedure the other interviews $(n=21)$ were conducted in 2011-2013.

The qualitative, semi-structured interviews were conducted mainly by the first author in dialogical, conversational interaction with the participants within a narrative research framework (Riessman, 2008). The main role of the interviewer was to create a trustful interview situation for the parents and to support and to listen to parents' narratives respecting the main themes of the study. Parents were asked to talk about the following main themes in the interview: (i) pleasant and unpleasant experiences of the educational partnership, and (ii) their experiences of their child in a daycare center. Parents were encouraged to describe their experiences, emotions and thoughts freely and, if needed, asked to elaborate by answering more specific questions. The interviews lasted on average 1 hour 10 minutes (ranging from about one hour to three hours).

\section{Data analysis}


All the interviews were audio-recorded and transcribed verbatim mainly by the first author. The purpose of the first phase of the analysis was to reach an understanding of the way parental agency was enacted in the relationship with educators. First, all the interviews were read carefully, and the episodes which contained parents' narratives of their agency in the educational partnership were extracted. Special attention was paid to the parents' narratives concerning their behavioural and communicational actions and initiatives in the educational partnership and the outcome of their agency. Next the different kinds of parental agency in the educational partnership present in the episodes were identified. After examining the similarities and differences between the kinds of agency identified in the episodes, three categories of parental agency were constructed. At the end of the first phase, all the selected episodes were re-coded into one of the three categories and the number of episodes in each category counted.

In the second phase, the emotions related to the three types of parental agency in the educational partnership were examined. Attention was especially paid to the parents' narration of pleasant and unpleasant emotions and the intensity of these emotions according to the circumplex model of emotions (Widen \& Russell, 2010). The emotions narrated by the parents were named and listed under these three categories. Ambivalent and neutral emotions were also identified. By utilizing the analytical framework of Vähäsantanen and Eteläpelto (2015) the following aspects were targeted for analysis: the starting points or triggers of enactment of agency; the emotions related to the enactment of agency; and, finally, the emotions the enactment of parental agency led to.

In the third phase, using narrative analysis (Polkinghorne, 1995), three narratives were constructed by the researcher to illustrate each category of parental agency. Each of them illustrated a different, typical way of enacting parental agency and the emotions related to it in the educational partnership. First, three interviews representing the most typical way of enacting agency in each category was selected from the data. These interviews contained more than $60 \%$ of the parental agency narrated in each category, and thus formed the core of each constructed narrative. Those narratives were then enriched by other parents' narration in the same category of agency in order to illustrate the variety in the parents' narratives. After that, the three constructed narratives were finalized and named. Pseudonyms were used throughout.

Findings: Parental agency, and related emotions, in the educational partnership 
The main findings of the study are presented as the three constructed narratives described in the previous section. Of the three types of parental agency identified, two were labeled active and the third was labeled hindered.

\section{Narratives of active parental agencies}

Two kinds of active parental agency were identified in the study: grateful partners with proactive agency and desperate fighters with confrontational agency. Most interviews contained some narration of proactive parental agency.

\section{Grateful partners with proactive agency}

The narrative of grateful partners included descriptions of proactive parental agency in the educational partnership accompanied by a moderate to high intensity of pleasant emotions. Typically, to support a child, the parents actively collaborated with the educators. For example, together with the educators, they 'helped the child to handle their emotions of anger and harm', as one mother reported. These parents participated actively at educational meetings and in everyday discussions with the educators. The parents also actively sought the help of other professionals for their child and for themselves.

Fear appeared to be one of the triggers of parental proactive agency. Parents were afraid of the consequences that difficulties in self-regulation would have for their child. Such parents 'didn't want their child to become a troublemaker' or 'to become a lonely child without any friends', as one mother put it. Parents were also worried that they were not coping adequately with the educational challenges their child presented and narrated feelings of inadequacy. Experiences like these led parents to undertake many actions and initiatives in the educational partnership. They expressed their need for support very openly when communicating with the educators. Jane felt she and her husband would not be able to cope as parents without the help of the professionals. 'The ordinary ways of parenting were just not enough' as she said. She felt so relieved at getting the educators as educational partners and not having to cope alone any more.

Parents asked the educators for advice on how to deal with the child's educational challenges and also welcomed advice and support from the educators with feelings of pleasure. Parents also emphasized the activeness of their role in the educational partnership: 'Obtaining support should be initiated by the parents, and the parents have to be active if they want to get support', as one father stated. The parents made suggestions and initiatives which 
were taken seriously by the educators. The parents narrated feelings of satisfaction and joy when their proactive agency produced positive results. The parents communicated important knowledge about their child to the educators which 'made the educators better understand the child's personality'. The parents narrated positive experiences of collaboration with the educators and of receiving positive feedback on their proactive agency from the educators:

We [the parents and the educators] always made plans for a common goal, and together we took small steps forward... And we got feedback from the educators saying that it has been so easy to cooperate with us. And we really have tried to make an effort at doing that.

Most parents emphasized the importance of the discussions in which child's individual educational plan (IEP) was drawn up together with the educators. Parents' thoughts and wishes were documented in the child's education plan, which made the parents feel their initiatives were important and noticed, as one mother stated:

I think it's important that it can be seen [in the child's individual learning plan], that the difficulties have been solved and that we as a family have been committed to the child's education. And what is very important is that it can be seen that we have coped at difficult times. And it was really great that we could write down our wishes, comments, agreements and disagreements by ourselves into the child's learning plan.

Parents also communicated openly with the educators when encountering challenges in the educational partnership. One mother asked the educators to deal again with a conflict between children in a daycare center in which her child was unfairly blamed. The mother was so happy when the conflict was finally resolved successfully by the educators. Parents' proactive agency led them to feel satisfaction and gratitude towards the educational partnership and the child's early childhood education. According to Jane, 'the cooperation has been so great' and they 'would have been lost without the educators'.

\section{Desperate fighters with confrontational agency}

The narrative of desperate fighters contained descriptions of confrontational parental agency in the educational partnership accompanied by a high intensity of unpleasant emotions. Fighters participated actively in parental meetings and other parental activities. They suggested, requested, wanted, demanded and ordered the educators to support their child's wellbeing in their struggle over what they felt to be in their child's best interests, as narrated by Mary: 
I acted like a tigress defending him [the child], and I had to tell them who he is.

I dragged our child forward, and in all possible ways with tooth and nail tried to find a place and a friend for him, and how much I wept because these were never found.

The triggers for parental confrontational agency can be interpreted as deep concern over the child's wellbeing in the daycare center. Parents narrated the distress and sorrow they felt, especially over the child's relationships with other children, and they were worried about whether the child was teased. These parents were also worried about the formation of a negative self-image, low self-esteem and a negative teacher-child relationship and expressed concern about whether their child carried the 'negative stigma of a bad boy'. Mary felt her child 'was not understood or liked' and 'he couldn't be the boy who he is in a daycare center'. One trigger for confrontational parental agency may be the feeling that the parents are the only ones who support the child. Mary narrated that she 'had to' make so many efforts to support her child because the child 'wasn't able to regulate his behavior'. She also said that if she 'hadn't done that, who would?' The situation caused the parents to feel anger, especially because they felt that the educators did not support their child.

These parents narrated that they did not share a common understanding with the educators regarding the child and child's difficulties. They described the personality and the behavior of the child in order to enhance the educators' understanding of the child. Mary asked the educators to visit their home so that they could better understand their child in the home context. She also communicated the relational needs of the child and suggested educational practices that could support the child's well-being in the daycare center. For example, she asked the educators 'to make the day schedule as clear and structured as possible' because environmental changes distressed the child. Parents expressed their worries as well as their expectations of good ECEC services to the educators. They were also courageous enough to talk about the challenges of the daycare center.

I said to the educators, I really hope you make an effort so that my child can be a part of this group...He's really challenging for us [the parents] too, but he cannot be the one, who do not have a place in the group. And he should be accepted in the group, and he should have a friend.

Unfortunately, parental active agency in these cases did not lead to positive results but instead to frustration and disappointment and for Mary to feelings of despair, guilt and sorrow. She felt guilty because she couldn't change the educators' understanding of the child and because of 'poor parenting, which may have caused their child's difficulties'. Feelings of 
guilt were strengthened because of 'all the harm and sick leave' the family had caused the educators. Mary described her experiences of the educational partnership as a relationship in which the partners were 'wearing different pairs of shoes all the time', and in which a common understanding and common goals were never reached.

\section{Hindered parental agency}

The parents with hindered agency narrated a few cautious actions and initiatives in the educational partnership that most typically were accompanied by ambivalent emotions. This finding is reported in the narrative of the confused receivers.

\section{Confused receivers with hindered agency}

The parents who showed hindered agency in the educational partnership made some cautious initiatives when cooperating with the educators. They narrated their dissatisfaction with the educational partnership when encountering what they perceived as unfair practices. However, they did not seek to influence these situations by practicing active agency. Lisa reported this as follows:

It was hard and frightening, day after day, to only get negative messages about our son. Soon I got to feeling that I just didn't want to go to the daycare center to collect our child, because I was so afraid of what might have happened that day. I so much longed to hear other kinds of messages too, because there were also good things about our child too... The stigmatizing of our child made me feel so sad and angry.

The parents narrated about many strong emotions like fear, worry and anger, when confronting situations like the one described above. The triggers for hindered parental agency can be understood to be emotional confusion. Parents with hindered agency seemed mostly to be uncertain parents with conflicting will, who several times, just after the event, knew how they should have acted in certain situations. Lisa said that as parents they 'should have put a stop to the negative path of stigmatizing the child earlier'. Narrating things in this way ('should have') implies that these parents wished they had practiced more active agency.

These parents were also afraid of the trouble their child might have caused during the day, like Lisa, who said, 'I was so afraid of what was happened'. This fear can be argued to have weakened their active agency and sometimes to have made them want to escape the situation. Lisa narrated feeling ambivalent emotions when she thought about some of the 
practices of the educators. She said she did not know whether it was a good thing or not that when a child was transferred from one group of children to another so too was the child's individual learning plan.

On the other hand it was really great that the papers of the child's individual learning plan were transferred together with the child... On the other hand, I sometimes got the feeling that I would soon be saying to the educators that you can't transfer these papers to another group because of the possibility of stigmatizing the child. But anyway, it was a good practice, because it was done in the child's best.

Parents also reflected on the challenging educational situations caused by their child's behavior from the educators' point of view, a process that may have further strengthened their ambivalent emotions. One mother narrated she 'understood the situation of the educators and how they were also as worried about the child as the parents'. These parents agreed that their child had frequently caused difficult situations for the educators in the daycare center. Some parents narrated how they were incapable of acting in certain situations. Lisa narrated how she was 'locked in helplessness' or how she 'just could not act' in some interactional situations. One parent narrated how, when she went to pick up her child, she was 'lying under the burst of the educators', i.e., she received negative feedback about her child's behavior. Parents made some cautious initiatives for better practices. Lisa expressed her wish to the educators that 'positive features of the child had also been recognized and documented'. However the parents felt their initiatives had no effect or they were ignored by the educators, which finally led to feelings of disappointment and anger.

In some interviews, hindered parental agency was related to the neutral emotions of the parents. One mother described her communication with a substitute educator in the daycare center. She said she 'could immediately see in the face of this educator if there was something negative to tell' when she came to pick up the child:

It was the day, when something had happened again, pinching or whatever it was... and the educator asked me 'would this be a reason for further medical investigation?' And at first I got the feeling I was being blamed, but then I thought that maybe this educator just didn't know everything about our situation... and another day when this educator told me that 'sand had been thrown down some other child's neck', I just said 'yeah, yeah'. And I thought that maybe this educator was thinking that this just doesn't interest me at all, but that wasn't so. My point was that it was nothing new for me. 
The previous episode was narrated with low emotional intensity. The mother initially felt she was being blamed, but after reflecting on the situation her emotions were more neutral. Some parents did not put too much weight on their negative experiences of the educational partnership, and nor did they seem to be worried about their child's wellbeing in the daycare center. As these parents mainly narrated good experiences of the educational partnership, they might not have had any reason to adopt a more active type of agency in these kinds of exceptional situations. One mother said she 'didn't bother talking about her concerns and burdening the educator' who was only working for a while in the daycare center. Some parents reflected on their responsibility and possibility for active parental agency in the daycare center. One mother, at home explaining the reason for her hindered parental agency in the situation, said that, as a mother, she 'can't influence negative behavior by her child in the daycare center'.

\section{Summary of the findings}

Proactive, confrontational and hindered types of parental agency were identified in this study (Table 1). Proactive parental agency in the educational partnership was typified by parental actions which led to a positive result. The parents with confrontational agency also acted and made initiatives in their interaction in the educational partnership. However, these initiatives were either not noticed by the educators or did not produce positive results. The parents with hindered agency made some cautious initiatives in the educational partnership, but with minimal influence.

The typical emotions of the parents with proactive agency in the educational partnership were worry, fear, relief, pleasure, joy and, finally, feelings of satisfaction and gratitude over the positive results of a successful educational partnership. The typical emotions of parents with confrontational parental agency in the educational partnership were intense worry about their child's situation, and distress, sorrow, anger, disappointment and frustration related to their negative experiences in seeking to enhance the educators' knowledge of their child and to support the child's wellbeing. These experiences led to feelings of despair and guilt at not being the kinds of parents they would have liked to be. The parents with hindered agency also narrated experiencing emotions of worry and fear. However, they most typically exhibited ambivalent emotions along with confusion and embarrassment. The enactment of hindered parental agency in the educational partnership finally led to unpleasant emotions like anger, 
disappointment and frustration, although also, in some cases, to emotional neutrality and calmness.

Table 1. Emotions related to the types of parental agency identified.

Table 1. Emotions related to the types of parental agency identified.

\begin{tabular}{|llll|}
\hline $\begin{array}{l}\text { Type of agency } \\
\text { Interviews }\end{array}$ & Proactive agency & $\begin{array}{l}\text { Confrontational } \\
\text { agency }\end{array}$ & Hindered agency \\
$\boldsymbol{n}_{\mathbf{1}}=\mathbf{2}, \boldsymbol{n}_{\mathbf{2}}=\mathbf{7}$ & $\boldsymbol{n}_{\mathbf{1}}=\mathbf{1}, \boldsymbol{n}_{\mathbf{2}}=\mathbf{1 9}$ \\
\hline Nature of agency & $\begin{array}{l}\text { Several initiatives } \\
\text { and activities noticed } \\
\text { and supported by the } \\
\text { educators }\end{array}$ & $\begin{array}{l}\text { Several initiatives, } \\
\text { activities and } \\
\text { demands ignored by } \\
\text { the educators }\end{array}$ & $\begin{array}{l}\text { Some cautious } \\
\text { initiatives having no } \\
\text { influence }\end{array}$ \\
$\begin{array}{l}\text { Collaborative } \\
\text { Triggers for }\end{array}$ & $\begin{array}{l}\text { Worry, fear } \\
\text { agency }\end{array}$ & $\begin{array}{l}\text { Worry, fear, } \\
\text { distress, sorrow }\end{array}$ & $\begin{array}{l}\text { Worry, fear, } \\
\text { uncertainty, } \\
\text { ambivalent emotions }\end{array}$ \\
$\begin{array}{l}\text { Emotions related } \\
\text { to enactment of } \\
\text { agency }\end{array}$ & Relief, pleasure, joy & $\begin{array}{l}\text { Anger, } \\
\text { disappointment }\end{array}$ & $\begin{array}{l}\text { Confusion, } \\
\text { embarrassment }\end{array}$ \\
$\begin{array}{l}\text { Enactment of } \\
\text { agency led to }\end{array}$ & $\begin{array}{l}\text { Satisfaction and } \\
\text { gratitude }\end{array}$ & $\begin{array}{l}\text { Anger, frustration, } \\
\text { despair, guiltiness, } \\
\text { shame }\end{array}$ & $\begin{array}{l}\text { Anger, frustration, } \\
\text { disappointment }\end{array}$ \\
$\begin{array}{l}\text { Constructed } \\
\text { narratives }\end{array}$ & Grateful partner & Desperate fighter & Confused receiver \\
\hline
\end{tabular}

Note: $n_{1}$ refers to the number of interviews comprising more than $60 \%$ of the narrative type, and $n_{2}$ refers to the number of interviews containing some amount of the narrative type.

Next, the similarities and differences in the emotions related to the three types of agency of the parents' narratives will be elaborated. All the parents narrated fear and worry concerning the wellbeing of their child in the daycare center. The emotions seemed either to activate or to freeze the parents' agency. Anger was most typically identified in the narratives of the confrontational and hindered types of parental agency. Anger was related to the confrontational type of agency in the constructed narrative of the desperate fighter. However, anger did not seem to lead the parents in the constructed narrative of the confused receiver to adopt a more active type of agency. The emotions of shame and guilt were most typically identified in the desperate fighter narrative, when the parents reflected on themselves as 
parents and educational partners. Shame was expressed about the harm the child in question caused the other children and the educators. Shame was also related to parents' reflection on their inability to "educate" their child to behave like the other "normal children" in the daycare center. Narratives of being "the wrong kind of parents" or "not good enough parents" were also typical of the desperate fighter narrative. These parents also felt guilty over their disagreements with the educators, which may be connected to their expectation that they should agree with the educators.

\section{Discussion and conclusions}

This qualitative study investigated parental agency and the emotions related in the educational partnership as narrated by the parents of children with difficulties in self-regulation. Three types of parental agency -proactive, confrontational and hindered- were identified in the educational partnership in the context of early childhood education, which mirror the study of Honkasilta et al. (2015) carried out in the school context. This study enriches these findings, since it also indicates emotions are closely related to parental agency. Typically, pleasant emotions were related to the proactive type of parental agency, which gave parents positive experiences of being able to influence their child's early childhood education and wellbeing in the daycare center. Unpleasant emotions in turn were related to the confrontational type of parental agency, which included resistance and taking a critical stance towards the educators (see also Hökkä et al., 2017). Ambivalent, and in some cases neutral, emotions were related to the hindered type of parental agency.

Positive experiences of the educational partnership and the pleasant emotions that arise from these experiences can also be interpreted as building trust and strengthening the proactive type parental agency whereas negative experiences build distrust and strengthen the confrontational or hindered types of parental agency (see also Adams \& Christenson, 2000; Poikonen \& Kontoniemi, 2011). The proactive parents very openly expressed their need for support when communicating with the educators and vice versa (see Edwards, 2005). They also talked about their educational challenges and disagreements openly with the educators, which imply mutual trust between the partners. The parents with confrontational agency, in turn, implied distrust by stating that if they as parents did not support their child then who would. 
The parents with proactive agency worked cooperatively with the educators. They shared concrete goals in the educational partnership and both parties were active in seeking to attain these goals. For example, together they helped the child to deal with anger and harming others. The partners drew on each other (see Edwards, 2005) in supporting the wellbeing and development of the child. The educators, in turn, enhanced proactive parental agency by, for example, acknowledging the parents' initiatives and by giving positive feedback on the parents' activities. This did not happen in the educational relationship for the parents with confrontational or hindered agency and neither did the two parties share common goals. Some parental goals such as finding a place and a friend for a child in the daycare center were also very difficult to achieve. In generally, parents' reflection on achieving their individual or common goals in the educational partnership was related to the emotions they experienced. Parents' moral reflection and judgements on their own activities and those of the educators were also associated with their emotions (see Schutz et al., 2006). Overall, the findings indicated that parental emotions related to the different types of agency were closely connected to the responses the parents received from the educators. All this emphasizes the relational and contextual nature of parental agency in educational settings (see also Honkasilta et al., 2015).

Although the contextual dimensions of agency (Eteläpelto et al., 2013) were emphasized in this study, it can be argued that both the personal and contextual dimensions were intertwined in the parents' narratives. Parents with confrontational agency can be described as courageous actors with good self-efficacy (Bandura, 2001), strong knowledge about their child and a clear understanding of what makes for good ECEC services. The parents with hindered agency in turn most typically narrated themselves as uncertain agents. Although interpretations of the connection between personality and parental agency cannot be made, personal factors matter in educational partnership. The parents' interview data also contained a lot of talk about their child and themselves as parents that reflected dominant cultural narratives (see Hänninen, 2000; 2004). For these parents, their child was not like the "ordinary child" in the daycare center (see Alasuutari \& Markström, 2011) and they reflected on themselves as not being "good enough parents" because they were unable to educate their child in how to behave. Dominant cultural narratives concerning parenting and daycare children should also be discussed when seeking to cooperate with parents of a child with difficulties in self-regulation, as such families are untypical.

This study investigated parental agency and related emotions in the educational partnership in ECEC context from the parents' point of view, a topic that has been little 
studied. Although the results are based on parents' subjective and relativist reality in a specific context (Spector-Mersel, 2010) they are reflected authentic situations. Even if direct generalizations cannot be made based on a narrative study (Riessman, 2008), this study furthers understanding of parental agency and related emotions in the educational partnership. However, to obtain a more complete understanding of the topic, educators' experiences need to be heard too. The reliability of this study was enhanced by carefully following the idea of transparency and ethics of narrative research throughout the research process (Heikkinen, Huttunen \& Syrjälä, 2007).

Finally, this study indicates that parental agency in the educational partnership cannot be described merely as volitional and intentional activities by parents in pursuit of their goals (see Bandura, 2001). In this study, emotions played important role in parental agency in the educational partnership, and hence greater attention should be paid to them. Emotions like fear, shame, anger and guilt should be discussed when working with the parents of children with difficulties in self-regulation. The discussion of emotions can promote parents' selfunderstanding and educators' understanding of parental agency in the educational partnership. It is also important to discuss the concrete, meaningful goals as well as the duties and responsibilities of both partners in the educational partnership. The findings showed that parental agency and emotions related were closely tied with the responses of the educators perceived by the parents. This study also indicated the meaning of emotions in educational partnership in ECEC context. Thus we suggest that the educators should be more aware of their own responses and related emotions, thoughts and attitudes when working with the parents of a child with difficulties in self-regulation. There should be a possibility for educators' collegial discussions and work consultation in order to understand the motives of parents' behaviour and in order to reach and maintain professional communication.

This study contributed to understanding of the importance of emotions in human agency. The results may be useful in supporting proactive parental agency in the educational partnership. Above all, this requires a parent-educator relationship based on mutual trust, respect and equality (Blue-Banning et al., 2004). Trust can be assumed to be of especial importance when working with the parents of children with difficulties in self-regulation. The development of trust need to be further investigated, and the perspectives of the educators should also be listened to, which will be the next phases of this research project.

\section{References}


Adams, K. S., \& Christenson, S. L. (2000). Trust and the family-school relationship examination of parent-teacher differences in elementary and secondary grades. Journal of School Psychology, 38(5), 477-497.

Alasuutari, M., \& Markström, A.-M. (2011). The making of the ordinary child in preschool. Scandinavian Journal of Educational Research, 55(5), 517-535.

Archer, M. (2000). Being human: The problem of agency. Cambridge: Cambridge University Press.

Archer, M. (2003). Structure, agency and the internal conversation. Cambridge: Cambridge University Press.

Bandura, A. (2001). Social cognitive theory: An agentic perspective. Annual Review of Psychology, 52, 1-26.

Barnes, B. (2000). Understanding agency. Social theory and responsible action. London: Sage.

Blue-Banning, M., Summers, J. A., Frankland, H. C., Nelson, L. L., \& Beegle, G. (2004). Dimensions of family and professional partnerships: Constructive guidelines for collaboration. Exceptional Children, 70(2), 167-184.

Bruner, J. (1990). Acts of meaning. Cambridge: Harvard University Press.

Burr, V. (2003). Social constructionism (2nd ed.). London: Routledge

Chen, J. (2016). Understanding teacher emotions: The development of a teacher emotion inventory. Teaching and Teacher Education, 55, 68-77.

Early Childhood Education Act (1973/2015) Retrieved from http://www.finlex.fi/fi/laki/ajantasa/1973/19730036 
Edwards, A. (2005). Relational agency: Learning to be a resourceful practitioner.

International Journal of Educational Research, 43(3), 168-182.

Elliott, J. (2005). Using narrative in social research: qualitative and quantitative approaches. London: Sage.

Emirbayer, M., \& Mische, A. (1998). What is agency? American Journal of Sociology, 103(4), 962-1023.

Eteläpelto, A., Vähäsantanen, K., Hökkä, P., \& Paloniemi, S. (2013). What is agency? Conceptualizing professional agency at work. Educational Research Review, 10, 45-65.

Foot, H., Howe, C., Cheyne, B., Terras, M., \& Rattray, C. (2002). Parental participation and partnership in preschool provision. International Journal of Early Years Education, 10(1), 519.

Giddens, A. (1984). The constitution of society: outline of the theory of structuration. Berkeley, Calif.: University of California Press.

Griffiths, C. B., Norwich, B., \& Burden, B. (2004). Parental agency, identity and knowledge: mothers of children with dyslexia. Oxford Review of Education, 30(3), 417-433.

Heikkinen, H. L. T., Huttunen, R., \& Syrjälä, L. (2007). Action research as narrative: Five principles of validation. Educational Action Research, 15(1), 5-19.

Honkasilta, J., Vehkakoski, T., \& Vehmas, S. (2015). Power struggle, submission and partnership: Agency constructions of mothers of children with ADHD diagnosis in their narrated school involvement. Scandinavian Journal of Educational Research, 59(6), 674-690.

Hoover-Dempsey, K., Whitaker, M. C., \& Ice, C. I. (2010). Motivation and commitment to family-school partnership. In S. L. Christenson \& A. L. Reschly (Eds.), Handbook of schoolfamily partnership (pp. 30-60). New York: Routledge.

Hänninen, V. (2004). A model of narrative circulation. Narrative inquiry 14(1), 69-85. 
Hänninen, V. (2000). Sisäinen tarina, elämä ja muutos. [Inner narrative, life, and change]. Acta Universitatis Tamperensis, 696.

Hökkä, P., Vähäsantanen, K., Paloniemi, S., \& Eteläpelto, A. (2017). The reciprocal relationship between emotions and agency in the workplace. In M. Goller \& S. Paloniemi (Eds.), Agency at work: an agentic perspective on professional and development (pp. xx-xx). Dordrecht: Springer.

Karila, K., \& Alasuutari, M. (2012). Drawing partnership on paper: How do the forms for individual educational plans frame parent-teacher relationship? International Journal about Parents in Education, 6(1), 15-27.

Lipponen, L., \& Kumpulainen, K. (2011). Acting as accountable authors: Creating interactional spaces for agency work in teacher education. Teaching and Teacher Education, 27(5), 812-819.

Murray, E., McFarland-Piazza L., \& Harrison, L. J. (2015). Changing patterns of parentteacher communication and parent involvement from preschool to school. Early Child Development and Care, 185(7), 1031-1052.

National core curriculum for pre-primary education 2014. Helsinki: Finnish National Board of Education 2016.

National curriculum guidelines on early childhood education and care in Finland 2016. Helsinki: Finnish National Board of Education 2016.

Ochs, E., \& Capps, L. (2001). Living narrative: Creating lives in everyday storytelling. Cambridge, MA: Harvard University Press.

Oxford Living English Dictionary. Retrieved from https://en.oxforddictionaries.com/ Poikonen, P.-L., \& Kontoniemi, M. (2011). Mutual trust between parents and preschool teachers. In M. Veisson, E. Hujala, P. K. Smith, M. Waniganayake \& E. Kikas (Eds.), Global 
perspectives in early childhood education. Diversities and possibilities. Baltische Studien Zur Erziehungs- Und Sozialwissenschaft, Bd. 20 (pp.383-397). Frankfurt am Main : Peter Lang AG.

Polkinghorne, D. E. (1995). Narrative configuration in narrative analysis. In A. J. Hatch \& R. Wisniewski (Eds.), Life history and narrative (pp.5-23). London: Falmer Press.

Posner, J., Russell, J. A., \& Peterson, B. S. 2005. The circumplex model of affect: An integrative approach to affective neuroscience, cognitive development, and psychopathology. Development and Psychopathology 17(3), 715-734.

Rautamies, E., Poikonen, P.-L., Vähäsantanen, K., \& Laakso, M.-L. (2016). Teacher-child relationships narrated by parents of children with difficulties in self-regulation. Early Child Development and Care, 186(11), 1846-1858.

Reynolds, A., \& Schlafer, R. (2010). Parent involvement in early education. In S. L. Christenson \& A. L. Reschly (Eds.), Handbook of school-family partnership (pp. 158-174). New York: Routledge.

Riessman, C. K. (2008). Narrative methods of the human sciences. Thousand Oaks, CA: Sage.

Rimm-Kaufman, S. E., \& Pianta, R. (2005). Family-school communication in preschool and kindergarten in the context of a relationship-enhancing intervention. Early Education and Development, 16(3), 287-316.

Rothbart, M. K., \& Bates, J. E. (2006). Temperament in children's development. In W. Damon, R. Lerner \& N. Eisenberg (Eds.), Handbook of child psychology (6th ed.) Vol 3: Social, Emotional and Personality development (pp. 99-166). New York NY: Wiley.

Sandberg, A., \& Vuorinen, T. (2008). Preschool-home cooperation in change. International Journal of Early Years Education, 16(2), 151-161. 
Schutz, P. A., Hong, J. Y., Cross D., I., \& Osbo, J. N. (2006). Reflections of investigating emotions educational activity setting. Educational Psychology Review, 18(4), 343-360.

Singer, J. A. (1995). Seeing one's self: locating narrative memory in a framework of personality. Journal of Personality, 63(3), 431- 457.

Spector-Mersel, G. (2010). Narrative research. Time for paradigm. Narrative Inquiry, 20(1), 204-224.

Summers, J. A., Hoffman, L., Marquis, J., Turnbull, A., Poston, D., \& Nelson, L. L. (2005). Measuring the quality of family-professional partnerships in special education services. Exceptional Children, 72(1), 65-81.

Turner, J. H., \& Stets, J. E. (2005). The sociology of emotions. Cambridge: Cambridge University Press.

Vähäsantanen, K., \& Eteläpelto, A. (2015). Professional agency, identity, and emotions while leaving one's work organization. Professions \& professionalism, 5(3), 1394- 1410 .

Zellman, G.L., \& Perlam, M. (2006). Parent involvement in child care settings: conceptual and measurement issues. Early Child Development and Care, 176(5), 521-538.

Webster-Stratton, C., \& Reid, M. J. (2010). A school-family partnership. Addressing multiple risk factors to improve school readiness and prevent conduct problems in young children. In S. L. Christenson \& A. L. Reschly (Eds.), Handbook of school-family partnership (pp. 204227). New York: Routledge.

Widen, S.C. \& Russell, J.A. (2010). Young children's understanding of others' emotions. In M. Lewis, J. M. Haviland-Jones \& L. F. Barrett (Eds.), Handbook of Emotions (pp. 348-363). New York: Guildford Press. 
